\title{
BENTURAN PERADABAN DAN CARUT- MARUT POSTMODERNISME
}

\author{
Muhammad Zain \\ Universitas Islam Negeri Alauddin Ujungpandang. \\ Jalan St Alauddin II Tip. (0411) 868156 homepage: ppb.uin.ac.id
}

\section{Abstract}

The paper aims to view the Huntington's ideas from different perspective that is postmodernism. The writer assumes that Huntington's thesis is much easier to understand if it is placed on postmodernism discourse. The outstanding characteristics of postmodernismare decentralization, deconstruction, de-consensus, and "condemned" modernism that is valued anti humanism and militarism. In postmodernism era, the meaning of the text is not on the text itself, but it is on the relationship between the text and the reader. In this era, there is a statement about the death of the writer (Barthes). Its views that inter-textuality has became the main source of th: fact. The relationship, hence, forms and also as the pouver. It means that who form the texts which are relevant to reality, truth, or values is powerful. The postmodernismera is a global era in which all events happened in the world even in the most remote part of the worid will be soon known and responded by the citizen of the world.

Key words: Huntington, text, postmodernism 


\section{Pendahuluan}

Corak budaya lokal, nasional, dan global ibarat ikan di laut, hidup berdampingan. Tetapi ketiganya tetap saja tunduk kepada hukum alam; dalam artian: yang besar dan kuat pasti memakan yang kecil, dan yang kecil akan "menghabisi" yang lebih kecil lagi: Ukuran besar atau kecil bukan hanya didasarkan pada jumlah kuantitas, akan tetap kualitas (Naim, 1997: 4).

Tulisan ini dimaksudkan untuk melihat gagasan-gagasan Huntington dalam perspektif yang lain, yakni, postmodernisme. Penulis (makalah) berasumsi, bahwa tesis Huntington akan lebih mudah dipahami jika "didudukkan" dalam wacana postmodernisme. Di antara ciri dan watak postmodernisme adalah: desentralisasi, dekonstruksi, de-konsensus, dan "mengutuk" modernisme yang dinilainya antihumanisme dan militerisme. Kecenderungan "penyederhanaan" dan menggeneralisasi masalah-masalah global yang demikian kompleksnya ala Huntington, tentu saja patut dianalisis lebih jauh. Pertanyaan sentralnya adalah: benarkah di masa depan akan terjadi the clash of civilization ("benturan peradaban yang berbeda") dan bukannya upaya perdamaian dan atau dialog? Bagaimanakah potret kesadaran beragama di era postmodernisme? Adakah kebangkitan Islam dan semangat konfusianisme merupakan ancaman bagi dominasi Barat? Atau keduanya hanyalah merupakan "kekuatan penyeimbang"?

\section{"The Clash of Civilization" ala Huntington}

Samuel P. Huntington seorang guru besar Ilmu Pemerintahan dari Harvard University menyulut polemik tidak terelakkannya konflik antar peradaban dalam peta politik dunia masa depan. Masa depan politik dunia, hemat Huntington, akan didominasi oleh benturan antar peradaban (clash of civilization) yang berbeda. la juga menyebut-nyebut, kolusi Islam-Kunfusianis sebetulnya akan bangkit untuk menentang dan melawan serta menghambat kekuatan, nilai-nilai dan kepentingan Barat. 
Untuk lebih jelasnya, berikut penulis mengutip pernyataan Huntington:

Menurut hipotesis saya, sumber utama konflik di dunia baru ini bukan lagi sesuatu yang pada dasarnya bersifat ideologis atau ekonomi, melainkan kultural. Faktor utama yang memilah-milahumat manusia dan sumber konflik paling besar di masa depan lebih bersifat kultural. Negara-negarabangsa tetap akan menjadiaktor paling kuat dalam percaturan dunia, tetapi konflik-konflik terbesar dalam perpolitikan global akan terjadi di antara bangsa dan kelompok dari berbagai peradaban yang berbeda...

Namun demikian, di Eurasia, perkembangan konflik antaretnis, yang contoh ekstrimnya dapat dilihat dalam kasus "pembersihan etnis", tidak sepenuhnya kebetulan. Konflik-konflik dibenuaitu adalah yang paling sering terjadi dan paling keras di antara berbagai kelompok dengan latar belakang peradaban yang berbeda. Di Eurasia, garisgaris pergesekan sejarah yang terjadi memisahkan berbagai peradaban, kembali memanas. Hal ini terutama benar di sepanjang perbatasan blok bangsa-bangsa Islam yang membentuk bulan sabit dari ujung Afrika ke Asia Tengah. Kekerasan juga berlangsung diantara kaum muslim di satu pihak, dengan umat (Kristen) Ortodoks Serbia di Bahkan, Umat Yahudi di Israel; Umat Hindu di India, Umat Budha di Burma, dan umat Katolik di Filipina. Islam dikelilingi oleh perbatasan yang penuh darah (Huntington, 1993:22; 34-35).

Bagi Huntington, identitas peradaban akan semakin penting di masa depan dan dunia akan dibentuk oleh interaksi antara tujuh atau delapan peradaban besar. Yakni Peradaban Barat, Konfusius, Jepang, Islam, Hindu, Ortodoks Slavia, Amerika Latin, dan mungkin juga Afrika. Adapun argumentasi yang diajukan Huntington, antara lain:

a. Perbedaan antara peradaban telah terbuktiselama berabad-abad sebagai pemicu konflik paling keras dan paling lama. Sedang peradaban itu sendiri telah terdiferensiasi oleh sejarah, bahasa, budaya, tradisi, dan yang lebih penting lagi agama. Perbedaan 
peradaban juga melahirkan perbedaan dalam memandang hubungan manusia dan Tuhan, individu dan kelompok, warga dan negara, orang tua dan anak, suami dan isteri, hak dan kewajiban, kebebasan dan kekuasaan, atau kesejahteraan dan hirarki.

b. Dunia sekarang semakin menyempit, interaksi antara orang yang berbeda peradaban semakin meningkat. Sehingga pada gilirannya akan menimbulkan kebencian bagi mereka yang berbeda peradaban. Seperti kebencian orang Perancis terhadap migran Afrika Utara, tetapi pada saat yang sama tidak demikian halnya bagi para imigran Polandia.

c. Proses modernisasi ekonomi dan perubahan sosial dunia membuat orang tercerabut dari identitas lokalnya. Gerakan-gerakan fundamentalisme agama-agama besar dunia seperti Kristen, Judaisme, Budhisme, Hinduisme, dan Islam rupanya dapat mengisi perbedaan ini. Menariknya, mereka yang terlibat dalam gerakan ini adalah kalangan muda yang berpendidikan universitas, profesional, teknisi kelas menengah dan pengusaha. Gerakan fundamentalisme agama dapat mengikis batas-batas negarabangsa. Agama dapat meluluhkan identitas lokal tadi. Contohnya, seorang muslim Mesir atau Aljazair pasti akan terusik melihat penderitaan dan pembantaian muslim Moro Filipina.

d. Supremasi dan kewibawaan Barat sedang terancam oleh kekuatan non-Barat. Seperti meningkatnya kecenderungan-kecenderungan "Asianisasi” Jepang, berakhirnya warisan Nehru di India dan berlangsungnya Hinduisme, gagalnya ide-ide sosialisme dan nasionalisme Barat dan kuatnya penetrasi "reislamisasi".

e. Karakteristik dan perbedaan budaya kurang bisa menyatu dan kompromi dibanding karakteristik dan perbedaan politik dan ekonomi. Lebih jauh lagi, agama dapat berperan dan atau "diperankan" sebagai alat untuk mendiskriminasi antar sesama manusia. Agama lebih kuat pengaruhnya ketimbang perbedaan etnik. Buktinya, orang bisa saja menjadi scparuh Perancis dan 
separuh Arab, dan dapat berwarga negara ganda. Tapi sangat sulit untuk menjadi setengah Katolik dan setengah Muslim,

f. Lahirnya kesadaran baru akan pentingya regionalisme ekonomi. Kecenderungan ini tentu saja berpengaruh pada perekonomian global (Huntington, 1993: 13-14).

Tak pelak lagi, tesis Huntington tersebut menyulut kontroversi. Di antara pakar yang menanggapi pandangan tersebut, antara lain:

\section{A. Dahana}

Asumsi Huntington ditolak secara tegas oleh A. Dahana. Menurut pengamat masalah Cina ini, sedikitnya ada tiga alasan kelemahan tesis tersebut. Yakni: (a) tidak ditemukan adanya "front persatuan internasional" antara negara-negara Arab radikal seperti Irak, Iran, Libya, Sudan dan Suriah untuk menentang hegemoni Barat, yang ada hanyalah hubungan perdagangan dan ekonomi (perdagangan senjata). Sedangkan hal lainnya tidak, walaupun dalam rangka membangun aliansi untuk menghadapi Amerika Serikat dan Uni Soviet. Hal terpenting dari Cina adalah kepentingan untuk menyebarkan komunisme model Cina kc seluruh dunia. Hal ini sejalan dengan cita-cita Mao Zedong untuk menyebarkan revolusi Komunis ala Cina. Hubungan Cina-Timur Tengah lebih disebabkan oleh motivasi ekonomis daripada ideologis; (b) penggunaan istilah kebudayaan konfusianis untuk merujuk kepada Cina dan Korea Utara adalah lidak benar dan sangat menyesatkan. Istilah ini biasanya digunakan secara umum untuk menyebut apa yang populer dengan bangsa-bangsa yang menggunakan Huruf Kanji. Oleh karenanya, konfusianis sebetulnya dapat diterapkan untuk menunjuk kepada Jepang, RRC, Taiwan, Kedua Korea (Utara dan Selatan), Hong Kong, Makao, dan mungkin juga Vietnam dan Singapura. (c) suatu teori dengan menggunakan argumentasi kebudayaan atau peradaban merupakan jalan pintas yang paling mudah untuk menerangkan 
sesuatu yang tidak dapat diterangkan dengan teori lain, padahal persoalan yang ingin dijelaskannya tidaklah sederhana. Anggapan bahwa dalam kebudayaan Cina, kekerasan dan balas dendam adalah faklor utama yang selalu hadir dalam menangani konflik. Sehingga demokrasi ala Barat sulit berkembang di Cina, lantaran kebudayaan tradisional Cina tidak pernah mengenal sistem egaliter, keterbukaan, transparansi. Kebudayaan Cina selalu memandang sesuatu berdasarkan kelas. Pemerintah Cina tak ubahnya seperti kekaisaran pada masa lain yang otoriter. Komunisme Cina sebetulnya merupakan amalgasi yang dikemas dari budaya Konfusianis Cina dan Marxisme-Lenimisme-Stalinisme yang dikemas menjadi pikiran-pikiran Mao Zedong. Sejumlah anggapan ini memang tidak seluruhnya ditolak. Akan tetapi bagaimana menerangkan proses demokratisasi yang sedang berlangsung dengan mulus di Taiwan dan Korea Selatan sejak pertengahan dasawarsa 1980-an. Padahal kedua negara itu, termasuk dalam kategori berperadaban Konfusianis, seperti Cina. Bahkan pemerintah Taiwan dengan terang-terangan menyatakan akan selalu mempertahankan sistem nilai yang diajarkan oleh Guru Kong atau Kong $\mathrm{Hu} \mathrm{Cu}$ (Dahna, 1993:32-35).

\section{Dewi Fortuna Anwar}

Beberapa bantahan Fortuna Anwar mengenai ketidakbenaran fantasi intelektual Huntington, diuraikan sebagai berikut:

a. Pasca perang dingin yang terjadi bukanlah kategorisasi masyarakat dan atau komunitas berdasarkan pengelompokan peradaban (sebagai entitas tertinggi). Akan tetapi merupakan perpecahan yang menuju entitas yang lebih kecil lagi, yaitu etnik atau suku. Contoh yang dilansir oleh Fortuna Anwar adalah terjadinya disintegrasi Uni Soviet, yang sebagian besar penduduknya memiliki dasar budaya yang sama. Ternyata kesamaan peradaban belum merupakan perekat yang cukup 
kuat bagi kelompok-kelompok etnis minoritas yang secara politik dan ekonomi merasa tertindas oleh kelompok mayoritas yang sedang berkuasa. Konflik yang barangkali terpanjang dalam sejarah bukanlah perang antar peradaban Barat dan Islam, tetapi intra-peradaban Barat, yaitu antara kelompok Katolik dan Protestan di Irlandia Utara yang sudah berlangsung sejak abad ke-16. Sumber konflik ini bukan semata-mata karena perbedaan agama, tapi lebih kepada kenyataan bahwa orang Irlandia merasa dijajah oleh orang Inggris yang berasal dari etnis yang berbeda (Huntington, 1993: 27-28).

b. Tidak selamanya pergesekan antara dua kultur yang berbeda pasti berpotensi konflik. Contohnya, kehadiran orang-orang Yahudi di Eropa. Meskipun selama ratusan tahun mereka mengalami diskriminasi di Barat terbukti dengan belum pupusnya perasaan anti-Yahudi atau anti-Semit di Rusia, Jerman dan termasuk juga Amerika Serikat. Akan tetapi mereka menguasai perekonomian dunia, sehingga mereka mendapatkan peranan politik yang sangat menentukan.

c. Argumen bahwa kemampuan negara-bangsa melemah untuk memberikan sumber identitas dan digantikan oleh agama adalah sulit dibuktikan. Peranan negara-bangsa tetap saja kuat, sepanjang hak-hak politik dan aspirasi rakyatnya tersalurkarn. Tidak dapat disangkal bahwa terjadinya gerakan fundamentalisme agama, baik di dunia Kristen atau pun Islam merupakan cerminan "keterasingan" mereka dari modernitas. Apakah gejala itu dapat dikatakan sebagai "pelarian" atau justru sebagai "peningkatan" keimanan? "Penetrasi keberagamaan" justru muncul untuk mengeliminir sekularisasi dan proses de-humanisasi dari kemodernan. Kalau demikian halnya, maka dapat dikatakan bahwa "kebangkitan agama" tidak perlu dicurigai sebagai sumber konflik masa depan, namun sebaliknya sebagai "peredam" terjadinya konflik antar-peradaban. 
d. Karakteristik dan perbedaan budaya tidak selamanya kurang bisa kompromi dibanding dengan perbedaan aspirasi politik dan ekonomi. Isu-isu global ternyata dapat mempersatukan manusia. Masalah-masalah global yang dimaksud seperti; masalah kemiskinan dan kelaparan, pencemaran lingkungan hidup, Aids, pengangguran dan mungkin juga penanganan narkoba. Tentu saja dalam menangani masalah-masalah global tersebut, kita tidak peduli perbedaan peradaban atau agama sekalipun. Yang merisaukan Huntington, sebenarnya bukanlah adanya kesadaran peradaban baru, akan tetapi hal itu sebagai bukti kemungkinan surutnya dominasi peradaban Barat, landas Fortuna (Huntington, 1993: 30-31).

3. Donald K. Emmerson

Emmerson dengan tegas menyatakan bahwa tidak mungkin para cendekiawan dan pejabat Amerika menantikan atau menghendaki aktualisasi "mimpi buruk" Huntington tentang konflik peradaban Islam-Barat. Emmerson merujuk pada kasus pluralitas di Indonesia sebagai negara yang mayoritasnya penduduknya adalah muslim dan membandingkannya dengan kondisi Amerika yang juga majemuk, baik dari segiagama maupun etniknya. Tentu kedua negara ini senantiasa menjaga keterbukaan (demokratisasi) dan toleransi antar budaya. Semboyan: Bhinneka Tunggal Ika (untuk Indonsia) dan E Pluribus unum (untuk Amerika) adalah hampir bermakna sama (Emmerson, 1983: 50).

4. Pandangan lain yang menolak tesis Huntington tersebut juga dikemukakan oleh John L Esposito; Chaibong Hahm; Mark R. Woodward; dan Richard Falk. Mereka ini menunjukkan kelemahan-kelemahan tcsis Huntington.

\section{Carut-Marut Postmodernisme}

Kata-kata, kunci yang lekat pada posmodernisme seperti dekonstruksi, difference, diskontinuitas sejarah, discourse, dan 
descentering menjadi seperangkat alat deteksi apa saja. Semuanya dapat saja dikait-kaitkan, dilihat serta dibahas dengan kaca mata posmodernisme. la menggoda tapi juga membongkar; ia mencerahkan, tapi juga mencemaskan, ia merealita tapi tak (sulit) terdefenisikan. la datang mengkritik kritik, mengusik kemapanan modernisme,menggusur monopolinya menggeser wacananya. Wacana yang tertindas, terpinggirkan, terperdaya menjadi terberdayakan. Narasi-narasi besar diketepikannya digantikan dengan narasi-narasi kecil. Majemuk, bergerak, tak hirarkis, tanpa perspektif, terputusputus, tak sistematis, itulah realitas posmodernisme (Sahal, 1994: 12).

\section{Postmodernisme; "menolak" Modernisme?}

Benarkah Postmodernisme datang untuk "mencukup sudah" kejayaan modernisme? Jika diasumsikan bahwa kehadiran Postmodernisme maka akan untuk "menolak" modernisme, adalah sulit memang sebelum kita memetakan modernisme itu sendiri. Modernisme dapat dimaknai terutama di bidang filsafat-adalah gerakan pemikiran yang diawali oleh inspirasi Rene Descartes, dikokohkan oleh gerakan pencerahan (englightenment/Aufklarung), dan mengaktualisasikan dirinya higga abad $X X$ lewat dominasi sains dan kapitalisme. Akan tetapi, janji-janji pencerahan modernisme berupa kebahagiaan total manusia, ternyata gagal, tak mewujud. Sejarah modernitas yang ditandai oleh dominasi rasio, muncul dalam baju sains yang kemudian mewujud menjadi saintisme telah menunjukkan dirinya sebagai "mitos baru".

Akibatnya, saintisme, industrialisasi berubah menjadi imperialisme, eksploitasi manusia atas manusia, superioritas Barat dan imperioritas Timur, nilai-nilai religi tergusur dan terpinggirkan. Nestapa manusia modern? Mereka mengalami krisis spiritualitas? Dominasi mayoritas memunculkan tirani minoritas. Muncul pemutlakan kebenaran; universalisme kebenaran rasio dan arogansi 
kekuasaan semakin menjalar. Belakangan muncul gerakan-gerakan postmodernisme untuk merevisi dan membongkar modernisme.

Lebih lanjut M. Amin Abdullah melakukan identifikasi cara berpikir (modes of thought) ala postmodernisme. Menurut M. Amin Abdullah, setidaknya ada tida struktur fundamental pemikiran postmodernisme itu, yakni: (a) deconstructiortism (pembongkaran kemapanan teori-teori); (b) relativisem (gugatan atas absolutisme); dan (c) pluralism (keanekaragaman). Untuk lebih konkritnya, berikut akan dipaparkan secara sederhana ketiga fundamental structure postmodernisme tersebut.

Tabel I Struktur Fundamental Pemikiran Postmodernisme ala M. Amin Abdullah

\begin{tabular}{|c|c|c|}
\hline & Maksudnya & Keterangan \\
\hline 1. Deconstructionism & $\begin{array}{l}\text { Upaya mempertanyakan, } \\
\text { mengkritik, menyanggah, } \\
\text { menolak dan atau } \\
\text { membongkar bangunan } \\
\text { teori (grand theory) mapan } \\
\text { yang telah dibangun } \\
\text { modernism. Selanjutnya } \\
\text { merumuskan teori baru } \\
\text { yang lebih relevan dengan } \\
\text { realitas sosial, } \\
\text { keberagaman, budaya dan } \\
\text { kemajuan Iptek. }\end{array}$ & $\begin{array}{l}\text { Teori M. Weber tentang } \\
\text { hubungan positif antara etik } \\
\text { (Etos) protestan dengan } \\
\text { semangat kapitalis tidak } \\
\text { dapat lagi menerangkan } \\
\text { realitas etik budhismedi } \\
\text { Vietnam, Srilangka, } \\
\text { Thailand dan Kamboja. } \\
\text { Walaupun Robert Bellah } \\
\text { telah membuktikannya } \\
\text { lewan penelitiannya pada } \\
\text { masyarakat budhisme } \\
\text { Jepang. Hasilnya ada } \\
\text { korelasi positif antara etika } \\
\text { Budisme dengan } \\
\text { peningkatan ekonomi dan } \\
\text { modernisme Jepang. }\end{array}$ \\
\hline 2.Relativism & $\begin{array}{l}\text { Kritis teradap penjelasan } \\
\text { yang berbau objektif, } \\
\text { absolut, dan universal. }\end{array}$ & $\begin{array}{l}\text { Dalam kasus dan batasan } \\
\text { HAM, negara industri } \\
\text { modern melihatnya sebagai } \\
\text { hal yang universal tidak } \\
\text { terkait dan terpengaruh } \\
\text { dengan sejarah dan budaya } \\
\text { setempat cenderung }\end{array}$ \\
\hline
\end{tabular}




\begin{tabular}{|l|l|l|}
\hline & & $\begin{array}{l}\text { mengikuti etka universal } \\
\text { Kant sementara negara } \\
\text { berkembang (dunia ketiga) } \\
\text { menganut HAM lokal- } \\
\text { kondisional, sangat terkait } \\
\text { dengan sejarah dan tempat } \\
\text { mengikuti historisisme } \\
\text { Hegel-Kant }\end{array}$ \\
\hline 3. Pluralism & $\begin{array}{l}\text { Sangat sulit untuk } \\
\text { mempertahankan } \\
\text { "paradigma tunggal" dalam } \\
\text { diskursus apa pun, yang } \\
\text { ada keanekaan, semuanya } \\
\text { perlu pendekatan multi- } \\
\text { dimensional approachhes }\end{array}$ & $\begin{array}{l}\text { Adanya kesadaran akan } \\
\text { pluralisme justru sebagai } \\
\text { medium dialog antar } \\
\text { agama-agama budaya dan } \\
\text { peradaban, bukan he clas of } \\
\text { civilization. }\end{array}$ \\
\hline
\end{tabular}

Struktur fundamental pemikiran postmoderriisme, sangat penting artinya dalam memahami secara tepat dunia warna-warni anatomi postmodernisme itu sendiri. Karena sangat boleh jadi, mengabaikan pandangan tersebut, kita akan terjebak dan mungkin saja salah kaprah dalam menilai postmodernisme. Tidak semua yang berbeda dengan modernisme adalah postmodernisme. Dan tidak semua unsur modernisme "ditolak" oleh postmodernisme.

\section{Gejala Postmodernisme dan Kesadaran Beragama Baru}

Menjelang ditutupnya abad 20, kita semua menyaksikan perubakin yang begitu pesat, cepat, komplek (penuh warna-wami) dan terkadang paradoksal. Paradoksal seperti 'melesetnya' prediksi John Naisbitttentang akan munculnya keajaiban Asia sebagai Newly industrial countries - negara-negara industri baru. Dasar prediksi tersebut adalah, karena laju pertumbuhan ekonomi negara-negara Asia sangatfantastik. Indonesia sendiri menunjukkan pertumbuhan ekonomi rata-rata 6-7\%.

Tapi pada kenyataannya yang terjadi adalah sebaliknya. Hampir seluruh negara Asia mengalami krisis ekonomi berkepanjangan. Fundamental ekonominya ambruk. Sehingga dapat disim- 
pulkan, ternyata paradigma berpikir matematis-kalkulatif tidak dapat lagi diandalkan sebagai satu-satunya paradigm (Asy'ari, 1998: 12).

Bencana ekonomi yang melanda negara-negara Asia menimbulkan berbagai ketidakstabilan, ketidakpastian, dan pesimisme global. Chaos terjadi bukan hanya ekonomi, tapi juga mengakibatkan kekisruhan politik, kegalauan kehidupan sosial-budaya. Dan terlantarnya tatanan nilai- moral yang ditawarkan agama Perlu dicatat bahwa, sistem perekonomian global telah berkembang sedemikian rupa sehingga komponen-komponennya juga berubah menuju ke arah sifat-sifat yang sebelumnya diabaikan; (a) virtual economy (ekonomi sermi); (b) invective (menjalar bagaikan virus); dan (c) floating (mengapung dan berputar secara global) (Piliang, 1998: 59).

Krisis ekonomi global sudah barang tentu tidak terjadi secara alami, tapi ada aktor intelektual dibalik. itu. George Soros adalah salah satu di antaranya. la sedang mendirikan sebuah "open Society institute" untukmembangun a global open society. Di dalamnya setiap individu bebas untuk melakukan global vision dan global intellegence dengan bergerak sesuai dengan keinginan niereka mengontrol dunia tanpa beranjak dari kursi ruang kerjanya. Dunia sedang terlipat. Masyarakat yang demikian itu menghilangkan batas-batas sosial. Wajah dunia yang seperti itu digambarkan oleh Yasraf A. Piliang sebagai berikut:

"Yang tercipta kini adalah dunia yang serba virtual uang virtual, utang virtual, ekonomi virtual, informasi virtual... Semuanya menjadi serba virtual, serba semu, serba tidak real.

Proses akhir sosial kini dipercepat dan mencapai keadaan maksimalnya di tangan media dan informasi (Televisi dan internet), yang menciptakan berbagai simulasi relasi social, yang ada sekarang bukanlah suatu komunitas yang diikatoleh satu ideologi politik tertentu, melainkan individu-individu yang satu sama lain bcrlomba dalam sebuah arena duel, konteks tantangan rayuan, godaan masyarakat konsumer (bukan konflik sosial ala Karl Marx). 
Akhir sosial juga ditandai oleh transparansi sosial, yaitu suatu kondisi lenyapnyakategorisosial, batas sosial, hirarki sosial yang sebelumnya membentuk suatu masyarakat. Batas antara dunia anak-anak dan dunia orang dewasa lenyap di tangan majalah porno, batas antara proletariat dan burjois lenyap dalam arena virtualisime konsumsi; batas antara penguasa dan teroris lenyap di tangan terorisme virtual, batas antara kebenaran dan kepalsuan lenyap di tangan virtualitas media dan informasi. Jaringan informasi menjadi transparan dan virtual, tatkala tak ada lagi kategorikategori moral yang mengikatnya, dan tak ada lagi ukuran-ukuran nilainya yang membatasinya (Piliang, 1994: 112-113).

Kegalauan dunia global seperti itu diperparah lagi dengan adanya isu "Milenium Bug" (computer clock) menjelang milenium ketiga. Komputer menjadi tidak cermat dan tidak tepat perhitungan data-datanya yang disimpannya menjadi tidak tertata. Dunia perbankan, kontrak ekspor, penjadwalan pesawat, komputerisasi listerik terancam. Dunia menjadi chaos dan respon dunia pun bermunculan. Sebagian melihatnya sebagai sebuah "bencana" atau kiamat, dan sementara yang lainnya memandangnya sebagai bukti ketidakmampuan manusia menggapai-NYA.Yang jelas, "milenium bug" ini telah meresahkan (Republika, 1994: 3).

Mencermati ekstremitas kehidupan global di atas, maka pertanyaan yang muncul kemudian adalah apa yang terbaik dan seharusnya kita ialukan? Di manakah peran agama? Apakah kita kembali menggali kearifan leluhur, seperti gotong-royong, koperasi atau dalam spiritualitas agama-agamalah rnerupakan jawabannya?

John Naisbitt dan Patricia Aburdene dalam Megatrends 2000nyu memprediksi milenium ketiga sebagai abad kebangkitan agama, Keduanya menyebut sebagai New Age (era baru) dengan slogan: Spirituality Yes, and Organized Religion. No! Keduanya banyak mengemukakan data-data konkrit mengenai kecenderungan manusia Barat yang "tiba-tiba" saja begitu haus dengan spiritualitas Timur. Mereka (penganut New Age) tidak peduli lagi dengan agama formal (Kristen dan Yahudi-Islam juga?) yang selama ini dianutnya. 
Kungkungan dan pengurungan agama formal dirasa tak sesuai lagi, tak mencerahkan lagi (Naisbitt, 1990: 254).

\section{Kebangkitan Agama-agama}

Era baru sama dengan agama baru? Roy Wallis - sebagai yang dikutip oleh Azyumardi Azra-memberi tipologi "nezv religion" (agama baru) dalam tiga kategori, yakni: (a) agama baru yang menolak dunia (the world rejecting new religion); (b) agama baru yang menegaskan dunia (the world affirming new religion); dan (c) agama baru yang mengakomodasi dunia (the world accommodating new religion) (Nafis, 1996: 20-30).

Mengapa timbul agama baru ini? Di antara penyebabnya adalah; (a) gagalnya sains dan teknologi dalam memberikan jawaban yang pas tentang makna (meanings) hidup. Kondisi ini diperparah lagi ketika sains -masih "netral" tidak berpihak, obyektif, mewujud menjadi saintisme - mengideologi, sarat dengan interest, kepentingan-kepentingan juga gagal menepati janji pencerahannya berupa kebahagiaan total kepada manusia, (b) agama-agama besar (formal) tidak mampu lagi mengapresiasi kebutuhan-kebutuhan manusia dan kemanusiaan; agama tidak lebih sebagai sekedar masalah hubungan individual dengan Tuhan (privatisasi agama). Agama tidak lampil sebagai suatu "kebutuhan publik" (public religion), kebutuhan bersama, (c) dalam perspektif postmodernisrne memang ada kecenderungan untuk merombak latanan keberagamaan "yang seragam", klaim universalisme agama mulai digugat dan diganti dengan kebenaran parsialistik, keutuhan subyek juga dipreteli dan diganti dengan "keterbelahan" subyek, kebenaran pihak lain sudah mulai "mengemuka". Dalam konteks ini, kecenderungan tersebut adalah sesuatu yang "'alami", dan dengan sendirinya tidak perlu dirisaukan.

Tak terbantahkan bahwa gerakan formulasi dan modifikasi "agama baru" adalah sesuatu yang "menggejala" dan atau mengglobal. Tidak hanya terjadi di negara-negara Barat yang notabene 
"pencipta" sains dan sering diklaim sebagai masyarakat pascaindustrial yang mengalami "kahampaan "spiritual. Tapi hal sama juga terjadi di negara berkembang yang hanya sebagai bangsa " penikmat-" -dalam batas-batas tertentu " korban" sains dan budaya barat. Seperti kasus "Haur Koneng" Tasikmalaya, merebaknya aliran kebatinan yang belakangan melebur menjadi "Kepercayaan Kepada Tuhan Yang Maha Esa", maraknya pendirian kelompokkelompok pendirian meditasi, terapi spiritual dan pengobatan.

Belakangan dan ini yang terkini adalah kasus $\mathrm{Hj}$. Lia Alimuddin yang mengaku telah mendapatkan wahyu dari Allahlewat malaikat Jibril. la mengaku bahwa Imam Mahdi, Mariam dan Jibril "menyatu" dalam dirinya. la juga menobatkan putranya sebagai Nabi Isa (Hidayat, 1998: 54).

Fenomena tersebut di atas menunjukkan bahwa, di era global ini agama bukan lagi sekedar persoalan pribadi (private), tapi merupakan persoalan publik. Oleh karenanya, agama adalah sesuatu yang seharusnya "deprivatisasi" (deprivatized). Dalam konteks inilah, agama tetap memainkan peranan penting di era global. Agama tidak berada di pinggiran apalagi tercerabut dari konteks sosial-budaya, ekonomi dan politik. Dengan sendirinya, berarti kebenaran nilai yang dikandung oleh sebuahagama bukan lagiatas nama pribadi (private), tetapi lebih merupakan hak masyarakat (public religion). Eksis dan atau bertahan lamanya sebuah "agama baru" juga sangat tergantung pada kedalaman nilai-nilai religius yang ditawarkannya (Evendy, 1997: 44).

Terkait dengan kebangkitan agama-agama, isu radikalisme agama-agama juga "mengemuka". Radikalisme agama atau biasa juga disebut dengan fundamentalisme, ortodoksi, konservatisme agama, sebetulnya dipicu oleh adanya radikalisme sosial dan ketidakpuasan politik. Jadi tidak murni atas nama dan memperjuangkan agama. Hanya menggunakan legitimasi dan otoritas agama sebagai simbol perjuangan. Jadi yang terpenting adalah pemenuhan hak-hak politik dan kepada yang berwenang dengan segera dapat 
menyelesaikan ketimpangan dan ketidak-adilan sosiai yang terjadi (Evendy, 1997: 45).

\section{Simpulan}

Simpulan yang dapat diambil dari tulisan di atas antara lain:

1. Bagaimanapun juga Huntington dalam "meng-issu-kan fantasi dan provokasi politiknya tetap terjebak dengan "narasi besar" yang melihat persoalan-persoalan global secara total. Sehingga ia scndin tidak mampu menerangkan aspek-aspek tertentu inter dan antar dari peradaban tertentu. Bagaimana menjelaskan fenomena perjuangan rakyat Palestina melawan Israel yang nota bene mereka itu terdiri dari masyarakal Muslim dan sebagiannya Kristen. Demikian pula perlawanan masyarakat muslim Afrika Selatan bersatu dengan orang kristen dalam menentang apartheid pen. Bagaimana menjelaskan bantuan Amerika Serikat kepada Arab Saudi yang anti praktek demokrasi ala Barat, sementara Amerika sendiri mengklaim dirinya sebagai negara yang paling bertanggungjawab atas pelaksanaan proses demokratisasi di belahan dunia ketiga. Di sini titik lemah pijakan argumentasi Huntington. la alpa dan tidak memperhatikan "narasi-narasi kecil" dan "yang tercecer" sebagai yang dipungut oleh pemikir postmodernisme (Muzani: 1993: 8-9).

2. Di era postmodernisme, makna sebuah teks tidak terletak pada teks itu, tapi pada relasi antar teks dan pembaca. Semuanya bebas ditafsirkan, tanpa melihat siapa pengarang atau penulisnya. Era postmodernisme adalah era "kematian pengarang atau penulis (kata Barthes). Kenyataan adalah relasi antar teks. Relasi itulah yang menbentuk, dan ia pula sebagai kekuasaan. Jadi kuasalah yang membentuk teks-teks berhubungan dengan realitas, kebenaran, ataupun nilai-nilai. Elite politik Barat dapat saja bersatu dengan elite politik Muslim karena ada kesamaan kepentingan kckuasaan, dan bukan karena mereka memiliki nilai-nilai 
kultural yang sama. Konkritnya, elite politik Muslim dapat saja berhubungan dengan elite politik Barat ketika ancaman dari Barat lebih kuat ketimbang dari rakyat mereka sendiri. Ataupun sebaliknya, elite politik Muslim bersatu dengan rakyatnya jika dipandang bahwa kekuatan rakyat lebih mengancam.

3. Dengan mempertimbangkan cara berpikir (modes of thought) dan dunia warna-warni postmodernisme hemat penulis, agama yang "laku"di pasaran global hanyalah agama yang mencerahkan, tidak mengurung, apalagimemasung. Agama yang inklusif, tidak fanatic, lapang, dan tetap mempertimbangkan nilai-nilai spiritualitas local, dan humanitas. Dengan sendirinya dapat dinyatakan bahwa kehadiran agamajustru dapat mengeliminir dan menghambat terjadinya "benturan antar peradahan". Tentu saja hal ini dapat terwujud jika nilai-nilai universal agama-agama dikedepankan, seperti nilai-nilai kemanusiaan, keadilan, kejujuran, dan kerendah-hatian. Gerakan radikalisme agama-agama yang notabene sebagai buah dari radikalisme sosial dan ketimpangan politik dapat dijinakkan dengan cara persuasif, mengajak mereka berdialog, bukan dengan kekerasan.

4. Era postmodernisme adalah era global; di mana peristiwa yang terjadi di belahan bumi paling ujung sekali pun dengan segera akan diketahui dan direspon oleh masyarakat dunia. Dunia rupanya memang sedang terlipat-dalam layar Televisi. Itu berarti peran media massa menjadi sangat penting. Akbar S. Ahmed umpamanya, pada awalnya sangat optimis dengan semangat pluralisme yang ditawarkan postmodernisme sehingga sangat dimungkinkan "dialog" Barat dan Timur (baca; Islam). Akan tetapi, pada kenyataannya, Barat justru melihat kebangkitan Islam tidak lebih sebagai sebuah "ancaman" daripada "teman dialog". Media massa Barat bagi S. Ahmed sebagai salah satu pemicunya, karena telah melakukan "kekerasan media" (mass rape). Itulah sebabnya, mengapa ia pada akhirnya inengutuk media massa (Barat)dengan menyebutnya sebagai"setan laknat" (evil demand). Ini berarti bahwa, "dialog antar peradaban" hanya 
bisa tercapai jika semua pihak dengan sungguh-sungguh ingin mewujudkannya. Di era posmodernisme, dialog antar agama dan peradabansangat memungkinkan mewujud. Hal mana, struktur fundamental dan atau alur berpikir postmodernisme, yakni: pluralisme (sadar akan "yang lain") sangat mendukung tugas kemanusiaan tersebut. Lagi pula, dengan dialog justru kedua belah pihak saling menguntungkan, bukannya lewat "benturan peradaban". Hemat penulis (makalah) kecenderungan eklektik yang juga merupakan tipikal posmodernisme sebagai salah satu ulasan memungkinkannya dialog tersebut diwujudnyatakan.

5. Sebagai akhir dari makalah ini, adalah menarik untuk mencermati laporan harian Kedaulatan Rakyal (Yogyakarta) yang menurunkan topik: "Prediksi Luar Negeri tahun 2000: Sistem ekstrem Punah, Arogansi Amerika Serikat Kena Batunya". Adapun berita utama yang dilansirnya, antara. lain: (a) Rusia dan Cina membentuk "Poros Timur" sebagai perimbangan kekuatan Amerika Serikat; (b) Upaya AS untuk memaksakan demokrasi dan 11AM ala Barat ditentang keras oleh Rusia dan Cina. Arogansi AS ternyata kontra-produktif; dan (c) Ekonomi juga ternyata sangat menentukan perimbangan kekuatan di dunia. Contoh: perang pisang AS dengan negara-negara Eropa; perang daging antara Inggeris dengan Perancis, perang apel antara Jepang dengan AS. Sebagai akibatnya, negara-negara maju memaksa negara-negara kecil untuk membuka pasarnya; serta (d) Bill Clinton menulis artikel dengan judul: 'The Challenges to Global Security" dalam Jane's Defence Weekly, Rabu, tanggal 2212-1999. Gagasan utama yang disampaikan Clinton adalah AS segera dapat merangkul Rusia dan Cina. AS "resah" melihat kemesraan keduanya, mendorong terjadinya transisi menuju demokrasi di berbagai negara, termasuk Indonesia dan Nigeria. Ternyata pemicu "pertentangan di masa depan" bukan disebabkan oleh "perbedaan antar peradaban", tapi lebih banyak dipicu oleh kepentingan politik dan ekonomi. Semangat kapitalisme belum juga pudar. 


\section{Daftar Pustaka}

Naim, Mochtar. 1997. Masa Depan Budaya Lokal di Era Globalisasi. dalam Republika, Jum'at 10 Oktober 1997.

Huntington, Samuel P. 1993. The Clash of Civilization dalam Foeign Affairs, 72, No.3, hal. 22; 34-35.

Idem. 1993. Benturan Antar peradaban, Masa Depan Politik Dunia. Terjemahan Saiful Muzani dalam Jurnal Ulumul Qur'an No. 5, Vol. IV, hal. 13-14.

Dahana, A. 1993. Konfusianisme Plus Islam Versus Barat?" dalam Jurnal Ulumul Qur'an, Vol. IV, Nomomr 5, hal. 32-35.

Moyniham, Daniel Patrick. 1993. Pandaemonium: Ethnicity in International Politics. New York: Oxford University Press.

Emmerson, Donald K. 1993. Konflik Peradaban Atau Fantasi Huntington?", dalam Jurnal Ulumul Quran, Vol. IV, no. 5, hal. 50.

Esposito, John L. 1995. The Islamic Threat: Myth Or Reality?. Bandung: Mizan.

Mahasin, Aswab. (Eds.). 1996. Ruh Islam, dalam Budaya Bangsa: Wacana Antar Agama dan Bangsa. Jakarta: Yayasan Festival Istiqlal.

Mark W, Woodward (ed.), 1998. Toward A New Paradigm: Recent

Developments in Indonesian Islamic Thought. Terjemahkan oleh Ihsah Ali Fauzi dengan judul: Jalan Baru Islam: Memetakan Paradigma Mutakhir Islam di Indonesia. Bandung: Mizan.

Falk, Richard. 1997. Geopolitik Penyingkiran terhadap Islam. Dalam Jurnal Ulumul Quran, Vol. VII, No.6, hal. 63-77.

Sahal, Ahmad. 1994. Kemudian, Di manakah Emansipasi? Tentang Teori Kritis Geneologi, dan Dekonstruksi" dalam Jurnal Kalam, Edisi I, tahun,12

Sugiharto, Bambang. 1996. Postmodernisme: Tantangan bagiFilsafat. Yogyakarta: Kanisius. 
Gellner, Ernest. 1992. Postmodernism, Reason and Religio. New York: Routladge.

Naisbitt, John. 1997. Megatrends Asia: The Eight Asian Megatrends That are Changing the World. London: Nicholas Brealey.

Asy'ari, Musa. 1998. Memaknai Suatu Krisis Membangun Paradigma Pemikiran lmajinatif. Pidato llmiyah pada rapat Senat Terbuka Dies natalis ke-47 IAIN Sunan Kalijaga. Yogyakarta, 26 September.

Piliang, Yasraf Amir. 1998. Sebuah Dunia yang Terlipat: Realitas Kebudayaan Menjelang Milenium Ketiga dan Matinya Posmodernisme. Bandung: Mizan.

Soros, George. 1995. On Soros: Staying a Head of the Curve. New York. Republika (laporan utama). 1998. Tinggat 400 Hari lagi, Sang Kutu Pembawa Kiamat Datang dan Jakarta 2000 dan Kiamat Milenium Bug. Tanggal.29 November.

Kleden, Ignas. 1995. Kebangkitan Agama dalam Tiga Dimensi, dalam Kompas, 3 April.

Azra, Azyurmadi. 1996. Kultus, dalam Muhammad Wahyuni Nafis (Eds.), Rekonstruksi dan RenunganReligius Islam. Jakarta: Paramadina.

laporan Majalah Gatra, nomor 42, tahun IV, 5 September, 1998, 24-33. Effendy, Bachtiar. 1997. Masyarakat Agama dan Tantangan Globalisasi: Mempertimbangkan Konsep Deprivatisasi Agama. Dalam Ulumul Quran, nomor 3. Vol. VII.

Muzani, Saiful. 1993. Benturan Islam-Barat suatu Proyek Di zaman Pasca-Modern. Dalam Jurmal Ulumul Quran, Vol.IV, No. 5.

Madjid, Nurcholish. 1995. Pintu-pintu Menuju Tuhan.Jakarta: Paramadina.

Nafis, Muharnmad Wahyuni dan Komaruddin Hidayat. 1995. Agama Masa Depan Perspektif Filsafat Perennial. Jakarta: Paramadina.

Ahmed, akbar S. dan Hasting Donnan. 1994. Islam, Globalization and Postmodemity, (eds.), London \& New York: Routledge. 
Abdullah, M. Amin. 1998. Falsafah Kalım. Jakarta: Paramadioa dan Gramedia Pustaka Utama.

Harian Kedaulatan Rakyat. 1999. Kamis, 23 Desember, hal. 1 dan 11. Rabi, Ibrahim M. Abu. 1987. Beyond the Postmodernism Mind, dalam The American Joumal of Islamic Social Sciences, Nomor 2,Vol. VII 